\title{
Impact of Remote and Local Sources on Particulate Matter in Urban Environment
}

\author{
Hesham A. Al-Jeelani \\ Department of Environmental Sciences, Faculty of Meteorology, Environment \& Arid land Agriculture, \\ King Abdulaziz University, Jeddah, Saudi Arabia \\ Email: yassin64@gmail.com
}

Received 16 January 2016; accepted 16 April 2016; published 19 April 2016

Copyright (C 2016 by author and Scientific Research Publishing Inc.

This work is licensed under the Creative Commons Attribution International License (CC BY). http://creativecommons.org/licenses/by/4.0/

(c) (i) Open Access

\begin{abstract}
In this paper, the impact of natural and anthropogenic sources on particulate matter with diameter less than $10 \mu \mathrm{m}\left(\mathrm{PM}_{10}\right)$ was investigated in Jeddah urban area, Saudi Arabia to identify and quantify the major particle pollution source classes. Hourly data of $\mathrm{PM}_{10}$ and other gaseous pollutants $\left(\mathrm{NO}_{\mathrm{x}}, \mathrm{CO}, \mathrm{SO}_{2}\right.$ and $\left.\mathrm{O}_{3}\right)$ and meteorological factors (temperature, relative humidity, atmospheric pressure, wind speed and wind direction) were collected at two air quality monitoring sites for the period of March 2008 to February 2009. The air mass origin was determined using 5-day backward trajectories arriving to Jeddah by using HYSPLIT model. Results show that the PM Daily Limit Value was exceeded. The most frequent air masses entering Jeddah and thereby influencing $\mathrm{PM}_{10}$ concentrations come from the East, specifically the SE and NE directions, 84\% of the trajectories were originated over the Arabian Peninsula including Saudi Arabia mainland and the Arabian Gulf. The Mediterranean Sea and southern Europe were the origin source of $8 \%$ of the air mass trajectories, another $8 \%$ were originated from North Africa and Sahara Desert. The majority of $\mathrm{PM}_{10}$ episodes were attributed to the intrusion of dust to Jeddah urban air.
\end{abstract}

\section{Keywords}

HYSPLIT Model, Meteorological Factors, Particulate Matter, Statistical Analysis, Urban Pollution

\section{Introduction}

Particulate matter (PM) is consisting of a mixture of particles that can be solid, liquid or both, are suspended in the air and represent complex mixture of organic and inorganic substances. Health problems related to particulate matter with an aerodynamic diameter of less than $10 \mu \mathrm{m}\left(\mathrm{PM}_{10}\right)$ arising from urbanization and industrialization have gradually created a demand for more efficient emission controls. In some cases, high $\mathrm{PM}_{10}$ concentrations 
have persisted over periods of several hours, resulting in exceedances of ambient air quality standards in daily and annual limit values. Various health effects attributable to PM have been documented [1]-[3]. The most conclusive evidence has been provided by cohort and time series studies that have linked elevated concentrations of PM to increased morbidity and mortality [4]-[7]. The majority of these studies have assessed the health effects of particles expressed as the risk per unit mass $/ \mathrm{m}^{3}$ of $\mathrm{PM}_{10}$ or $\mathrm{PM}_{2.5}$. Contribution from major desert dust events to PM has been reported in numerous studies conducted in Europe [8], North-America [9], Asia [10] and Australia [11]. Southern Mediterranean countries experience several transient episodes (2 - 4 days) of transported Saharan dust each year, leading to levels exceeding $25 \mu \mathrm{g} / \mathrm{m}^{3}$ and $10-15 \mu \mathrm{g} / \mathrm{m}^{3}$ in daily $\mathrm{PM}_{10}$ and $\mathrm{PM}_{2.5} \mathrm{Con}_{-}$ centrations, respectively [12]. The effect of seasonal phenomena on soil related fine and coarse particles has been reported from different regions around the world [13]. Querol et al. [14] investigated the origin of PM in seven European regions using $\mathrm{PM}_{10}$ and $\mathrm{PM}_{2.5}$ measurements from a range of regional, urban background and kerbside monitoring stations. Hellack et al. [15] carried out a PM10 source apportionment study in Berlin by comparing the chemical composition of particles collected at urban background, regional background and kerbside locations. It was concluded that approximately 50\% of the urban PM10 background was related to long-range transport and natural particle sources. Markus Sillanpää et al. [16] investigated the chemical composition of fine $\left(\mathrm{PM}_{2.5}\right)$ and coarse $\left(\mathrm{PM}_{2.5-10}\right)$ particulate matter in 7-week field campaigns of contrasting air pollution at six urban background sites in Europe. The results indicated that the measured $\mathrm{PM}_{2.5}$ and $\mathrm{PM}_{2.5-10}$ in the campaigns could be reconstructed to a large extent with the help of harmonized particulate sampling and analysis of the selected chemical constituents. Several hundred of $\mathrm{PM}_{10}, \mathrm{PM}_{2.5}$ and $\mathrm{PM}_{1}$ daily samples were collected by by Mazzei et al. [17] in sites of the urban area of Genoa (Italy) with different geo-morphological and urbanization characteristics. They could identify and quote the contamination of anthropogenic PM in "natural" sources (sea, soil dust). A new sampling methodology was devised and applied by Amato et al. [18] to collect $\mathrm{PM}_{10}$ deposited mass from $1 \mathrm{~m}^{2}$ of road pavement. $\mathrm{PM}_{10}$ road dust fraction was sampled directly from active traffic lanes at 23 sampling sites during a campaign in Barcelona (Spain).

Finally, in Saudi Arabia and the Arabian Gulf, wind-blown dust is a daily event when the wind velocity exceeds the threshold value. $\mathrm{PM}_{10}$ may travel over hundreds to thousands kilometers downwind. PM from desert for example cause a number of $\mathrm{PM}_{10}$ exceedances in the surrounding areas of the Kingdom of Saudi Arabia, Kuwait, Iraq, Greece, Spain and South Korea [13]. A cursory examination in the Arabian Gulf including Saudi

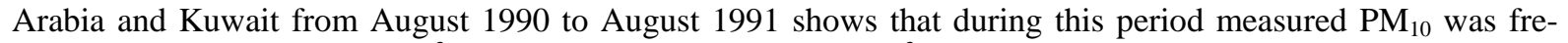
quently in the $100-200 \mu \mathrm{g} / \mathrm{m}^{3}$ range (although $100-200 \mu \mathrm{g} / \mathrm{m}^{3}$ may not be considered low in many other regions), for the large-scale events $\mathrm{PM}_{10}$ was $>1000 \mu \mathrm{g} / \mathrm{m}^{3}$ [19] (Draxler et al. 2001). Another related issue, using satellite AVHRR imagery, Walters et al. [20] documented the number of days for which blowing dust was observed for individual source areas during August 1990-31 March 1991. He estimated that there were 44 dusty days over Kuwait in the 235 day period or about $18.7 \%$ of the time. The average annual number of days of dust in Kuwait given by Safar [21] was $10.4 \%$ which shows that the number of dusty days was above average at least in Kuwait. High $\left(\mathrm{PM}_{10}\right)$ levels have been observed in several Saudi cities, including Jeddah [22].

The main goal in this study concerned to study the effect of remote and local sources including natural and anthropogenic sources on $\mathrm{PM}_{10}$ concentrations in two locations in Jeddah city from March 2008 to February 2009. Thus, the aim of the study was to: (a) Investigate the long range transport of $\mathrm{PM}_{10}$ as specific urban air quality problem in the study area; (b) Study the relationship between $\mathrm{PM}_{10}$ level and other gaseous pollutants $\left(\mathrm{CO}, \mathrm{NO}_{\mathrm{x}}, \mathrm{SO}_{2}\right.$ and $\mathrm{O}_{3}$ ), and meteorological factors (relative humidity, temperature, atmospheric pressure, wind speed and wind direction). To accomplish this aim, the collecting of air quality data, HIGHSPLIT model, was used to investigate the impact of remote and local sources on $\mathrm{PM}_{10}$.

\section{Methodology}

\subsection{Study Area}

Jeddah is the second largest city in the Kingdom of Saudi Arabia with over 3.6 million registered populations, is situated on a flat coastal area by the Red Sea at latitude $21^{\circ} 35^{\prime} \mathrm{N}$ and longitude $39^{\circ} 15^{\prime} \mathrm{E}$. The city has a complex urban environment constituting a mix of commercial, residential, and industrial establishments. Large industries including industrial estate area, refineries, and power plants are situated to the south, desalination plant to the west and solid waste landfill to the east of the city. Jeddah is a developing city with rapid urbanization underway, heavy traffic congestion and a thriving economic growth, the growing air pollution problems are something to be 
concerned about. Two air quality monitoring stations (Figure 1) were located along Madina Road as a part of PME air quality monitoring network. Stadium shelter site is located at the Ministry of Education Stadium, close to the intersection of Madina Road with Rawdha Street (Kubry alMuraba'), it is a "hot spot" area that experiences heavy traffic influence with commercial, residential urban background. Ruwais shelter site is located at al Ruwais District around $200 \mathrm{~m}$ from Madina Road, the site is consider to be residential, traffic urban background, the station is temporarily located at this site and will be relocated to another area designated by PME.

\subsection{Monitoring Data}

This study was based on data collected during one year period from March 2008 to February 2009. Continuous measurements of $\mathrm{PM}_{10}$ and other gaseous pollutants includes $\left(\mathrm{NO}_{\mathrm{x}}, \mathrm{NO}, \mathrm{NO}_{2}, \mathrm{CO}, \mathrm{SO}_{2}\right.$ and $\left.\mathrm{O}_{3}\right)$ and meteorological parameters includes [temperature $\left({ }^{\circ} \mathrm{C}\right)$, relative humidity $(\mathrm{RH})$, barometric pressure (BP), rainfall (RF), wind speed (WS) and wind direction (WD)] were conducted on hourly basis during the study period. Quality check was performed to assure data validation. $91 \%$ and $87 \%$ of data were obtained for Stadium and Ruwais stations respectively.

\subsection{Back Trajectory Modeling}

Air quality models are widely used tools in studying source-receptor relationships. Among them, the Hybrid Single-Particle Lagrangian Integrated Trajectory (HYSPLIT) [23] [24], model is a commonly used air modeling program that can calculate air mass paths from one region to another and thus demonstrate whether the vector for air pollutant transport is indeed present. The output of the HYSPLIT model can vary from simple air parcel trajectories to complex dispersion and deposition simulations. HYSPLIT calculates advection and dispersion using either puff or particle approaches under a Lagrangian framework. The HYSPLIT model uses a hybrid

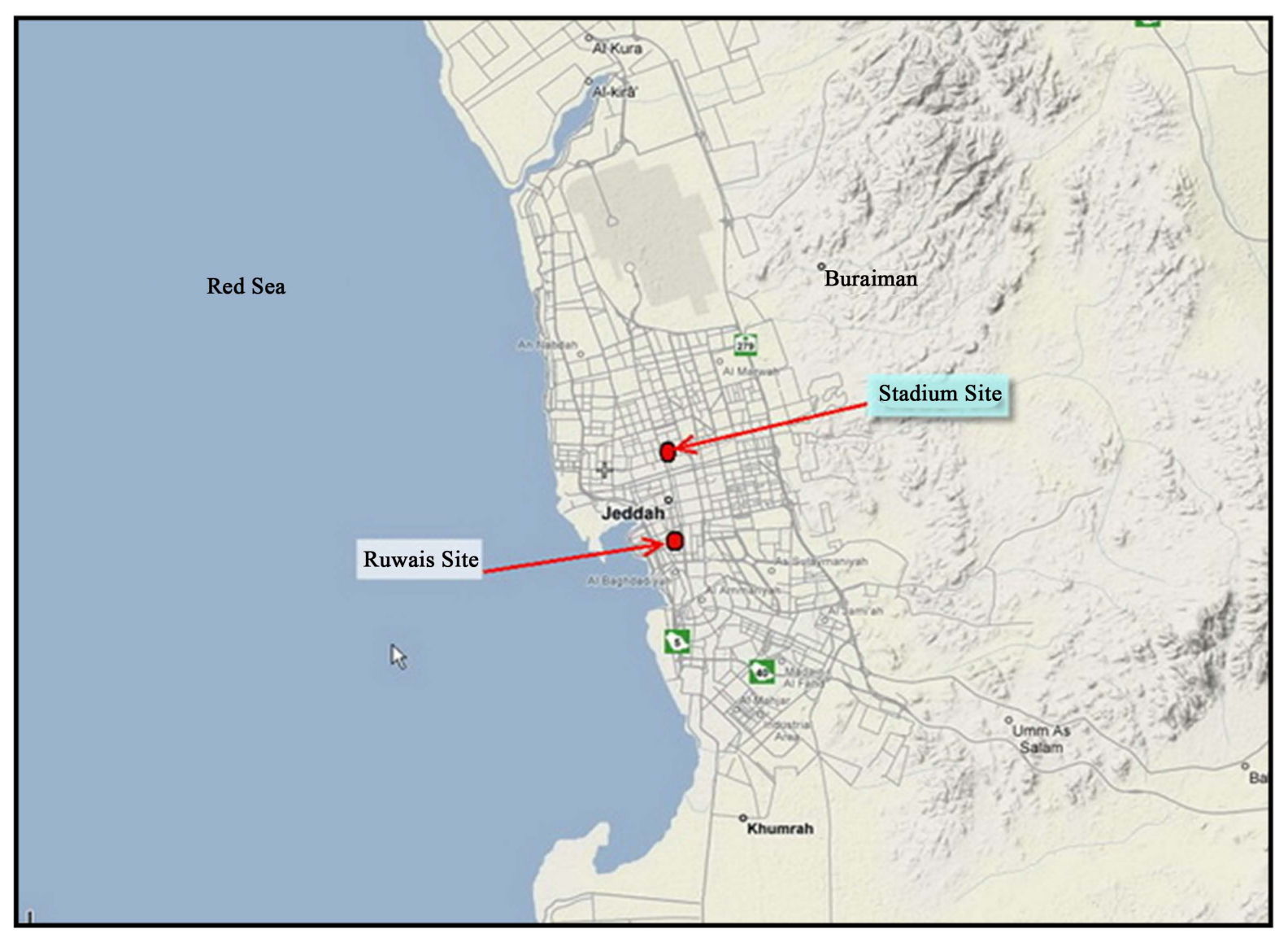

Figure 1. Location map of monitoring stations discussed in this study. 
approach, in which the calculation employs puff distribution in the horizontal direction and particle dispersion in the vertical. The trajectory calculation is achieved by the time integration of the position of an air parcel as it is transported by the 3-D winds. By moving backward in time, the resulting back trajectory indicates air mass arriving at a receptor at a particular time, thus identifies the source region.

The differential trajectory equation is:

$$
\mathrm{d} P / \mathrm{d} t=V[P(t)]
$$

A common solution to this equation is to expand $P(t)$ in a Taylor series about $t=$ to evaluated at $t_{1}=t_{0}+\Delta t$; and about $t=t_{1}$ evaluated at $t=t_{0}$. The resulting first guess position is:

$$
P(t+\Delta t)=P(t)+V(P, t) \Delta t
$$

And the final position is:

$$
P(t+\Delta t)=P(t)+0.5\left[V(P, t)+V\left(P^{\prime}, t+\Delta t\right)\right] \Delta t
$$

Equation (3) is accurate to the second order, and it has been determined that higher order methods do not yield greater precision.

\subsection{Statistical Analysis}

In order to investigate the local contribution to $\mathrm{PM}_{10}$ concentrations, the dataset were statistically analyzed. Descriptive statistics, frequencies, diurnal and weekly variations were performed. Associations of $\mathrm{PM}_{10}$ to the other pollutants and meteorological parameters were investigated with the Pearson's correlation coefficient. The analysis was initially carried out using daily $\mathrm{PM}_{10}$ concentrations paired with concurrently measured concentrations of gaseous species $\left(\mathrm{NO}_{x}, \mathrm{CO}, \mathrm{SO}_{2}\right.$ and $\left.\mathrm{O}_{3}\right)$ and meteorological parameters (air temperature, relative humidity, atmospheric pressure, wind speed and wind direction). Linear regression analysis was applied to examine the significant correlation coefficients. Statistical analyses were performed with the SPSS. MM $_{10}$ roses were plotted for the dataset using WRPLOT View.

\section{Result and Discussion}

\subsection{Diurnal Distribution}

Average diurnal variation of $\mathrm{PM}_{10}$ over the study area is shown in Figure 2. The diurnal variation of $\mathrm{PM}_{10}$ shows an early morning and late night peak $\left(\approx 84 \mu \mathrm{g} / \mathrm{m}^{3}\right)$ during 21:00-08:00 LT. The $\mathrm{PM}_{10}$ level between 11:00 and 17:00 LT records the minimum value of $\left(\approx 70 \mu \mathrm{g} / \mathrm{m}^{3}\right)$ at both sites. The increase in $\mathrm{PM}_{10}$ concentration during early morning and late night hours has been mainly attributed to the wind circulation. In a coastal city like

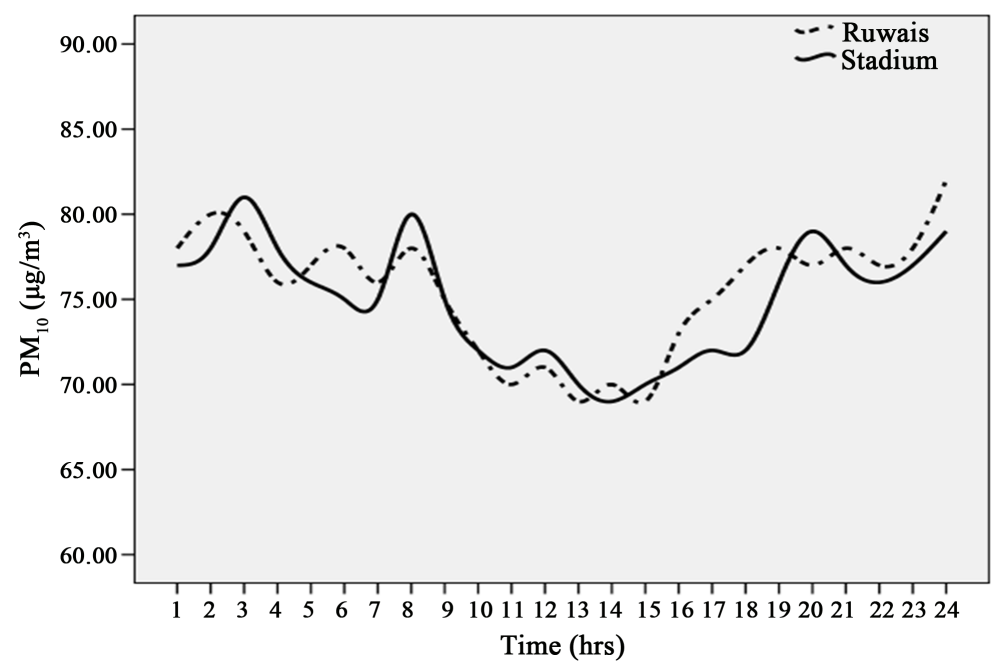

Figure 2. Average diurnal variation of $\mathrm{PM}_{10}$ concentrations during study period. 
Jeddah, sea and land breeze circulation play a major part in the diurnal distribution of $\mathrm{PM}_{10}$. $\mathrm{PM}_{10}$ emissions from human activities during daytime accumulates as the wind weaken at night, resulting in an increase in concentration as seen in the early morning late night hours over the study area. The solar heating of the land also increases during daytime resulting in increased boundary layer height. This increase in boundary layer height leads to faster dispersion of aerosols and a subsequent decrease in concentration of particulate matter. By evening hours, solar forcing is cut off and the boundary layer height decreases, leading to increase in concentration of particles. Similar diurnal behavioral observations have been reported in other studies [25].

\subsection{Analysis of PM10 Episodes}

The distribution of the daily average $\mathrm{PM}_{10}$ concentrations shows a very similar magnitude for both sites for all dataset (Figure 3 and Figure 4). USEPA's 24-hr standard limit of $150 \mu \mathrm{g} / \mathrm{m}^{3}$ was exceeded in 38 days. The figures show the seasonal variation in $\mathrm{PM}_{10}$ concentrations, maximum values of $784,725,615 \mu \mathrm{g} / \mathrm{m}^{3}$ appeared in

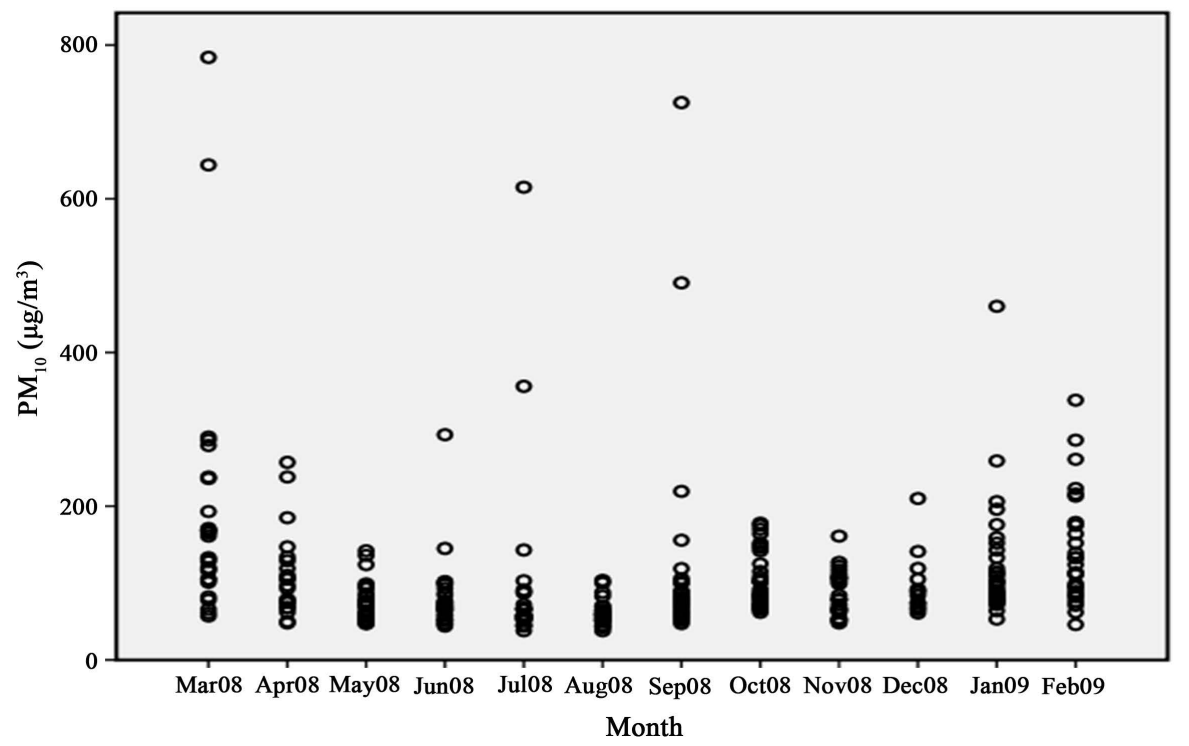

Figure 3. Distribution of daily $\mathrm{PM}_{10}$ at Stadium site during study period.

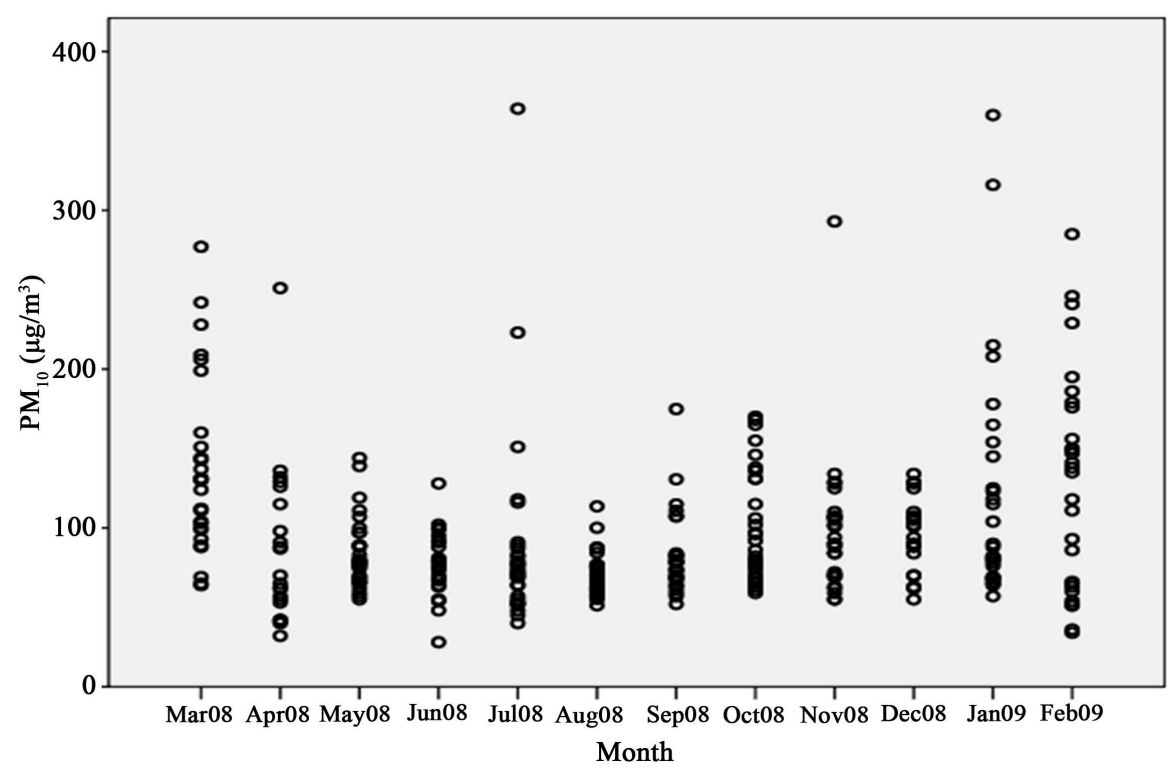

Figure 4. Distribution of daily $\mathrm{PM}_{10}$ at Ruwais site during study period. 
March, September and July 2008 respectively. These values were four to five times higher than USEPA's 24-hr standard limit. The episodes were classified into 13 cases according to the duration of each case. The exceedances were distributed all over the studied period; the maximum days with exceedances were in March 2008 and February 2009 with 13 and 9 days respectively.

\subsection{Comparison between the Two Monitoring Sites}

The two sites were located in urban and traffic areas and thought to be representative of typical population exposure in large areas. The daily $\mathrm{PM}_{10}$ concentrations correlated very strongly between the two monitoring sites. Pearson correlation $(\mathrm{R}=0.885)$ shows very strong correlation is significant at the 0.01 level. Scatter plot and regression analysis is shown in Figure 5, clear linear relation $\left(\mathrm{R}^{2}=0.783\right)$ between $\mathrm{PM}_{10}$ levels at stadium and at Ruwais location. Nevertheless, there were certain marked differences between the two monitoring sites. For example, Stadium site appeared to be strongly affected by road traffic sources.

\subsection{Relationship between PM10 and Other Pollutants}

Figure 6 showed monthly average values for $\mathrm{PM}_{10}$ and $\mathrm{NO}_{\mathrm{x}}, \mathrm{SO}_{2}, \mathrm{O}_{3}$ and $\mathrm{CO}$ during the study period at Stadium site. Peak values of $\mathrm{PM}_{10}$ on March, April 2008 and January, February 2009 revealed the seasonal variations of $\mathrm{PM}_{10}$ suggesting maximum concentrations in winter and spring and minimum in summer. The figure showed positive relation of $\mathrm{PM}_{10}$ to $\mathrm{NO}_{\mathrm{x}}$ and $\mathrm{SO}_{2}$, and negative relation to $\mathrm{O}_{3}$. The relation between $\mathrm{PM}_{10}$ and $\mathrm{CO}$ was not clear. Figure 7 shows monthly average values for $\mathrm{PM}_{10}$ and $\mathrm{NO}_{\mathrm{x}}, \mathrm{SO}_{2}, \mathrm{O}_{3}$ and $\mathrm{CO}$ during the study period at Ruwais site. There is a tendency of high $\mathrm{PM}_{10}$ concentrations on March 2008 and January, February 2009 revealed the seasonal variations of $\mathrm{PM}_{10}$ suggesting maximum concentrations in winter and spring and minimum in summer. As in Stadium site, possible positive relation of $\mathrm{PM}_{10}$ to $\mathrm{NO}_{\mathrm{x}}$ and $\mathrm{SO}_{2}$, and negative relation to $\mathrm{O}_{3}$. The relation between $\mathrm{PM}_{10}$ and $\mathrm{CO}$ was not clear. Pearson correlation was performed between $\mathrm{PM}_{10}$ and gaseous pollutants to investigate the possible relationship. Table 1 shows Pearson correlation coefficients between daily $\mathrm{PM}_{10}$ and gaseous pollutant concentrations in both sites during the study period. The correlation between $\mathrm{PM}_{10}$ and other gaseous pollutant concentrations was generally weaker in Ruwais, which is probably due to the distance from roadside compare to Stadium. The correlation between $\mathrm{PM}_{10}$ and $\left(\mathrm{NO}_{\mathrm{x}}, \mathrm{NO}\right)$ was generally moderate $(\mathrm{R}=0.353$ and $\mathrm{R}=0.347)$ respectively, and more consistent in Stadium site, demonstrating to some extent the common road traffic, mainly vehicular origin of primary $\mathrm{PM}_{10}$ and $\mathrm{NO}_{\mathrm{x}}$ and $\mathrm{NO}$ in urban areas.

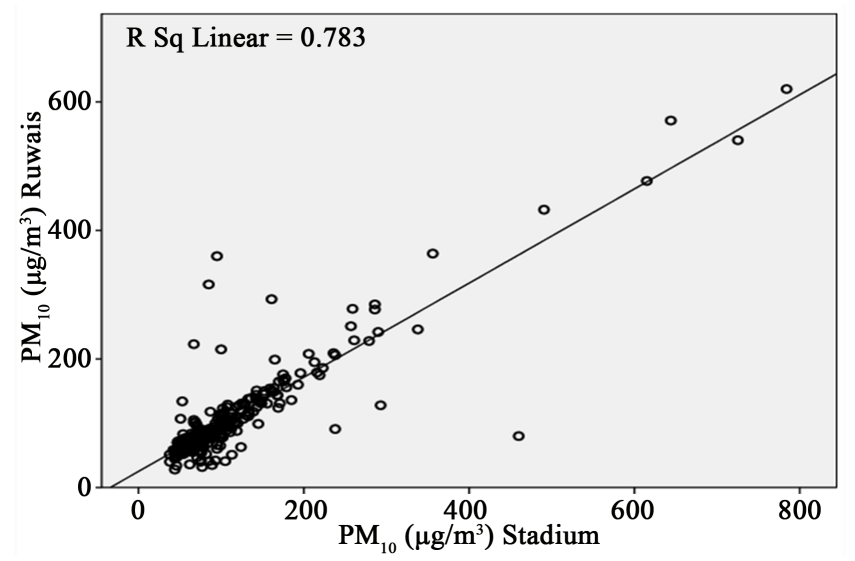

Figure 5. Scatter plot of $\mathrm{PM}_{10}$ at Stadium vs. $\mathrm{PM}_{10}$ at Ruwais during study period.

Table 1. Pearson correlation coefficients between daily $\mathrm{PM}_{10}$ and gaseous pollutant concentrations in Jeddah during the period from March 2008-February 2009.

\begin{tabular}{ccccccc}
\hline Site & $\mathbf{C O}$ & $\mathbf{N O}_{2}$ & $\mathbf{N O}$ & $\mathbf{N O}_{\mathbf{x}}$ & $\mathbf{O}_{3}$ & $\mathbf{S O}_{2}$ \\
\hline Stadium & 0.146 & 0.241 & 0.347 & 0.353 & -0.276 & 0.201 \\
Ruwais & 0.116 & 0.185 & 0.296 & 0.261 & -0.203 & 0.166 \\
\hline
\end{tabular}




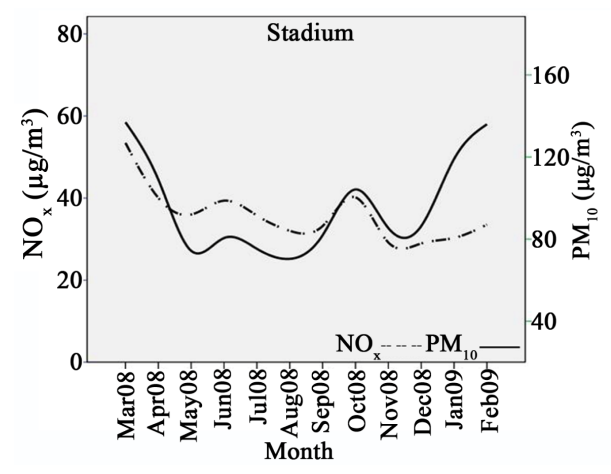

(a)

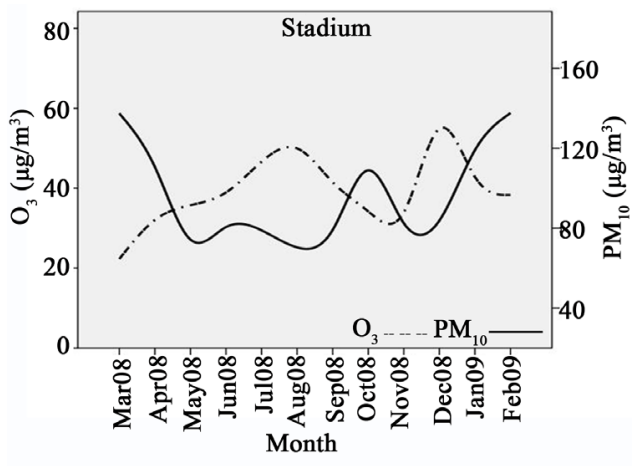

(c)

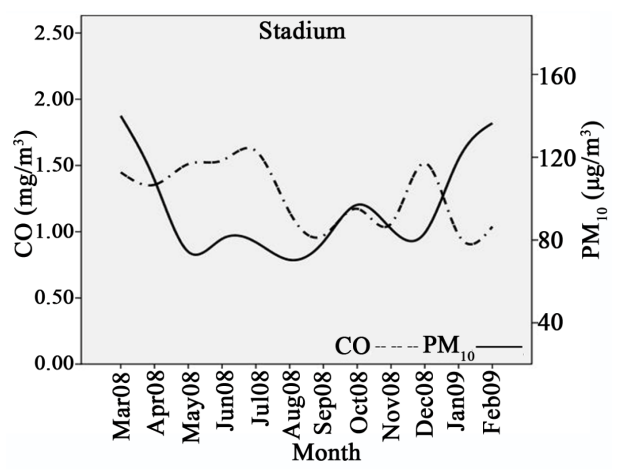

(b)

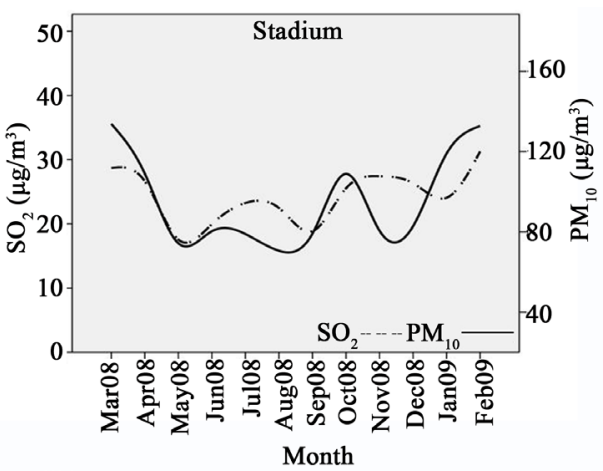

(d)

Figure 6. Monthly variations of $\mathrm{PM}_{10}$ and (a) $\mathrm{NO}_{\mathrm{x}}$ (b) $\mathrm{CO}$ (c) $\mathrm{O}_{3}$ and (d) $\mathrm{SO}_{2}$ at Stadium site during study period.

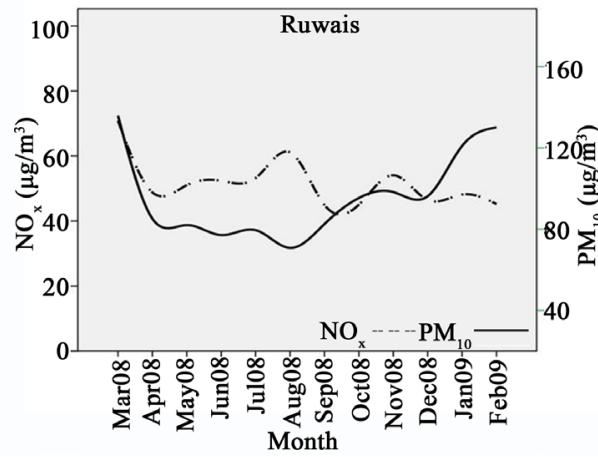

(a)

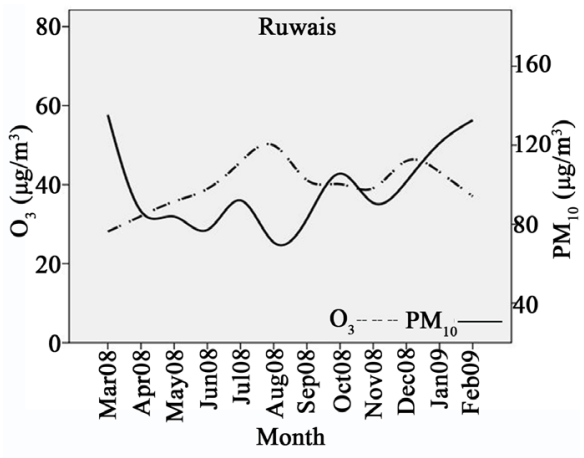

(c)

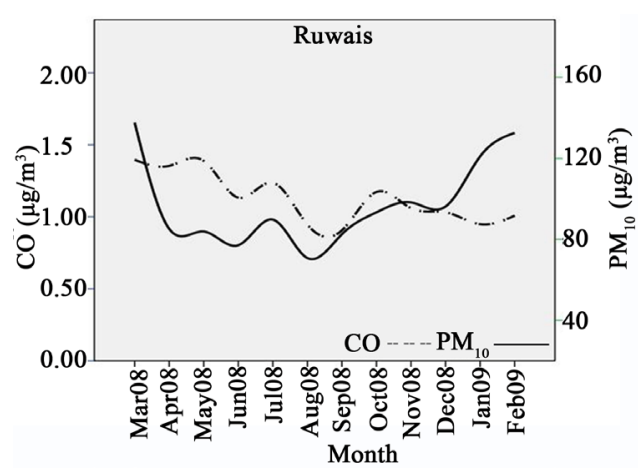

(b)

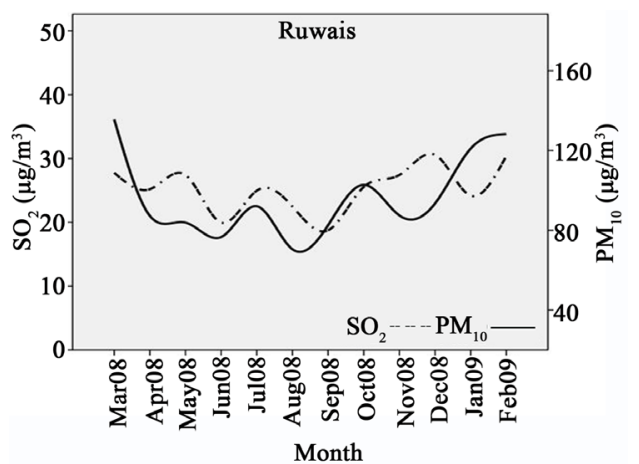

(d)

Figure 7. Monthly variations of $\mathrm{PM}_{10}$ and (a) $\mathrm{NO}_{\mathrm{x}}$ (b) $\mathrm{CO}$ (c) $\mathrm{O}_{3}$ and (d) $\mathrm{SO}_{2}$ at Ruwais site during study period. 
The correlation between $\mathrm{PM}_{10}$ and $\mathrm{SO}_{2}$ was weaker in Ruwais $(\mathrm{R}=0.166)$ than Stadium $(\mathrm{R}=0.201)$, suggesting insignificant correlation between combustion processes as a source of $\mathrm{SO}_{2}$ and the daily $\mathrm{PM}_{10}$ concentrations. The correlation between $\mathrm{PM}_{10}$ and $\mathrm{CO}$ was very weak in Ruwais $(\mathrm{R}=0.116)$ and Stadium $(\mathrm{R}=0.146)$. Daily mean $\mathrm{O} 3$ concentrations correlated negatively with $\mathrm{PM}_{10}$ at both sites. This negative correlation can be explained by the reaction of $\mathrm{O}_{3}$ with $\mathrm{NO}$, which is a major sink for ozone. Daily mean $\mathrm{PM}_{10}$ concentrations were regressed against $\mathrm{NO}_{\mathrm{x}}$ and $\mathrm{NO}$ values averaged over the study period at Stadium site. The correlation coefficients of the linear regression of $\mathrm{PM}_{10}$ against $\mathrm{NO}_{\mathrm{x}}$ and $\mathrm{NO}$ were generally weak $\left(\mathrm{R}^{2}=0.146\right.$ and $\left.\mathrm{R}^{2}=0.128\right)$ and suggest that approximate effect of different sources may contribute to the total $\mathrm{PM}_{10}$ concentrations at this site.

\subsection{Relationship between $\mathrm{PM}_{10}$ and Meteorological Factors}

Figure 8 showed monthly average values for $\mathrm{PM}_{10}$ and temperature, relative humidity, atmospheric pressure and wind speed during the study period at Stadium site. The figure showed negative relation of $\mathrm{PM}_{10}$ to temperature and wind speed and positive relation to relative humidity and atmospheric pressure. There is a tendency of high $\mathrm{PM}_{10}$ concentrations to be associated with high pressure values, low temperatures and low wind speed. The same trend is shown in Figure 9 for Ruwais site. These indicate the significant seasonal variation of $\mathrm{PM}_{10}$ with meteorological factors. The $\mathrm{PM}_{10}$ dependence on wind direction gave the distribution of local emission sources around the monitoring sites. In both sites, $\mathrm{PM}_{10}$ levels were generally affected by the sources from north direction. However, higher $\mathrm{PM}_{10}$ concentrations were associated mainly with easterly winds, more specific from NE

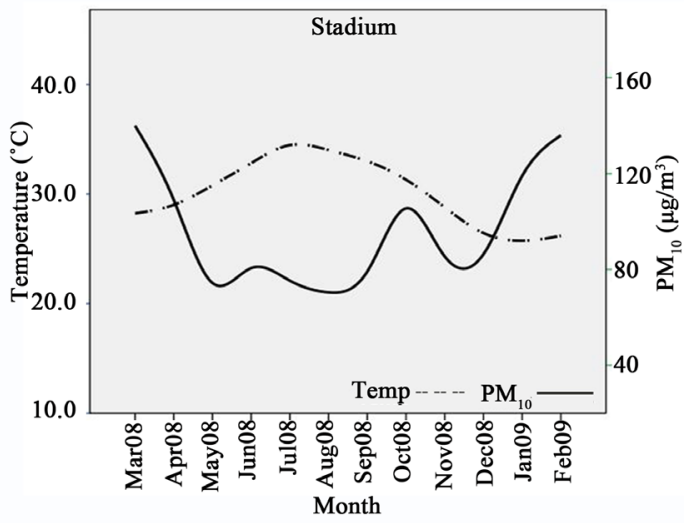

(a)

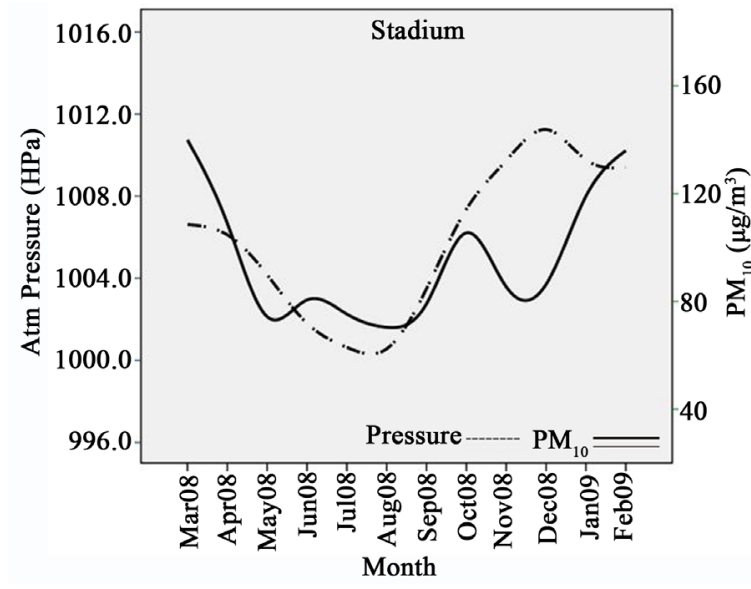

(c)

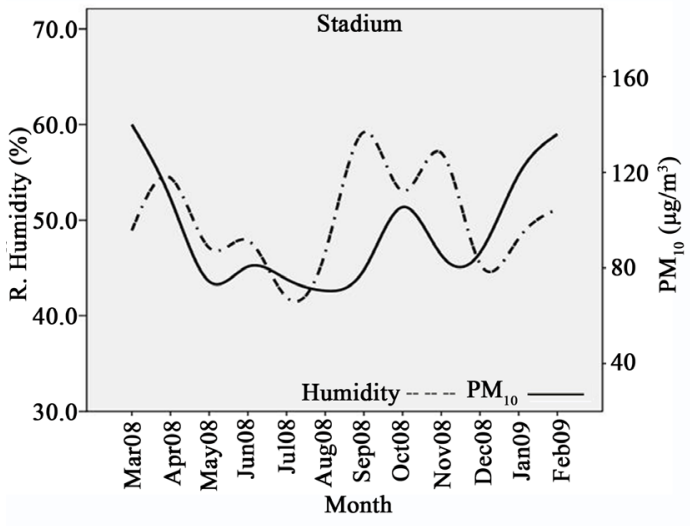

(b)

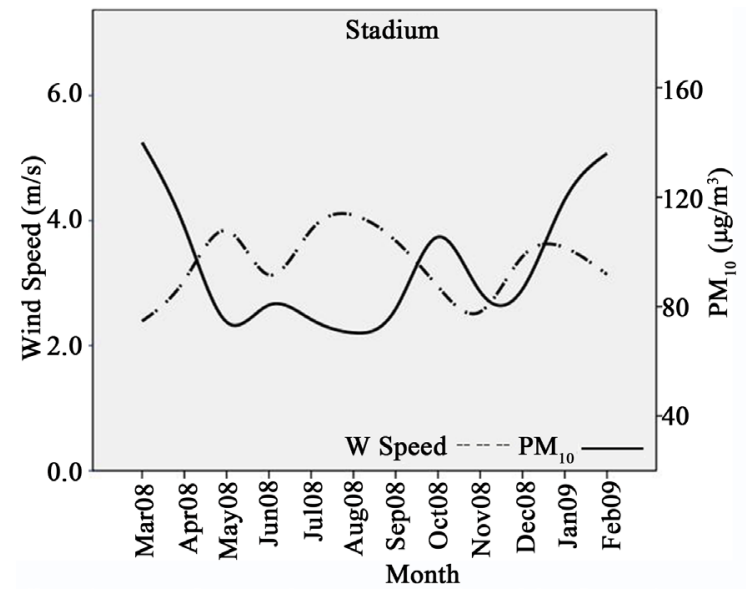

(d)

Figure 8. Monthly variations of $\mathrm{PM}_{10}$ and (a) temperature (b) relative humidity (c) atmospheric pressure and (d) wind speed at Stadium site during study period. 


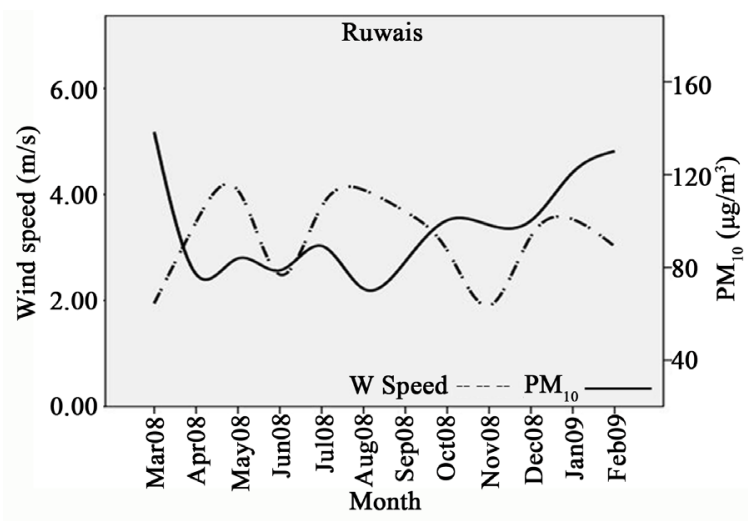

(a)

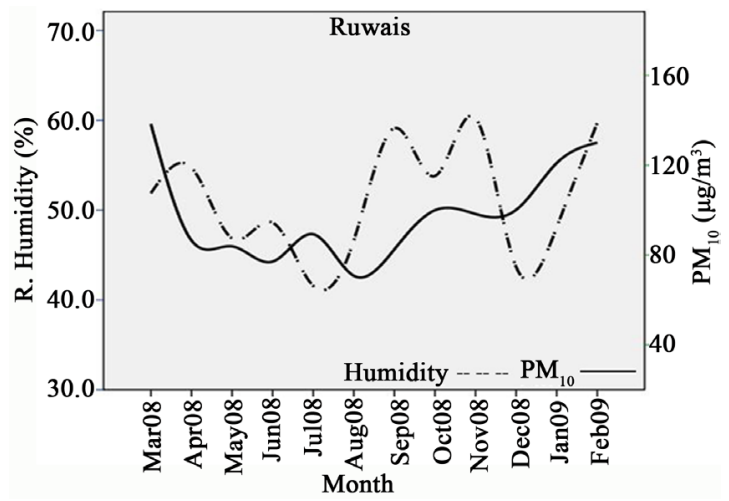

(c)

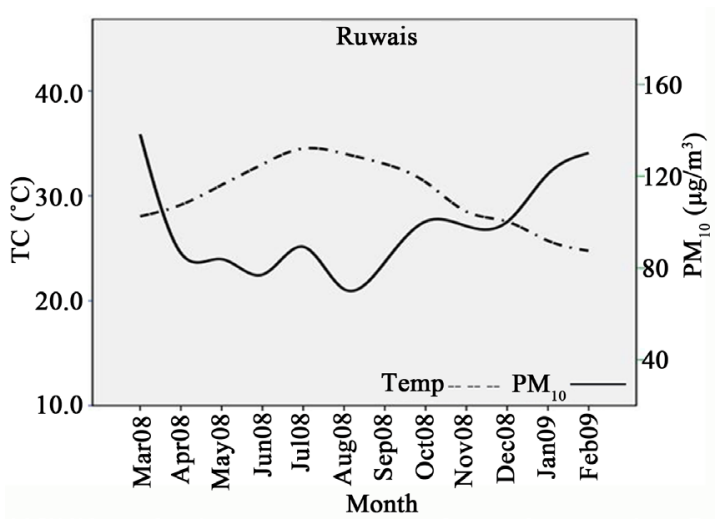

(b)

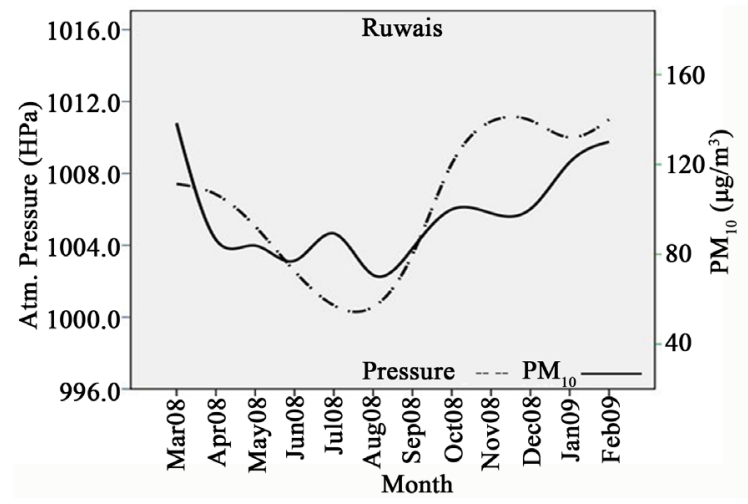

(d)

Figure 9. Monthly variations of $\mathrm{PM}_{10}$ and (a) temperature (b) relative humidity (c) atmospheric pressure and (d) wind speed at Ruwais site during study period.

and SE directions. In Table 2, daily $\mathrm{PM}_{10}$ concentrations correlated negatively with wind speed $(\mathrm{R}=-0.311$ and $\mathrm{R}=-0.379)$ at Stadium and Ruwais sites respectively. The reason that strong winds are generally expected to disperse locally generated air pollution. However, they can also enhance $\mathrm{PM}_{10}$ levels under certain meteorological condition, due to wind-blown dust and the re-suspension of soil and road dust. The correlation analysis between $\mathrm{PM}_{10}$ and temperature was negative at both sites, but at Ruwais $(\mathrm{R}=-0.190)$ was weaker than Stadium $(\mathrm{R}=-0.231)$, which confirms the hypothesis of reduced dispersion on stable atmospheric conditions during night time and faster dispersion of aerosols during daytime, due to the solar heating of the land. Positive correlation between $\mathrm{PM}_{10}$ and atmospheric pressure was probably attributed to the seasonal variation and the weather regime that contribute to dust intrusions to the study area. Finally, there were non-significant correlation between $\mathrm{PM}_{10}$ and relative humidity.

\subsection{Back-Trajectories Analysis.}

Figure 10 shows 5-days backward trajectories ending at Jeddah 0000 UTC (0300 LST) on 6 March 2008, which corresponds to the first peak (case 1-March 2008) in Figure 10. Figure 11 shows 5-days backward trajectories from 1200 UTC 23 March 2008, which corresponds to the second peak (case 2-March 2008) in Figure 11. The figures clearly show that all the three air masses started from over a desert region in southern and eastern Arabian Peninsula. In case 1, the sudden increase of PM10 concentration indicates the intrusion of dust storm event which resulted in severe air pollution episode in Jeddah. This is considered to be the typical urban air pollution episode for Jeddah during dust/sandstorm events. In case 2, gradual increase in $\mathrm{PM}_{10}$ concentration indicates that the hazy weather as reported by meteorological observation is the main cause of $\mathrm{PM}_{10}$ episode. In both cases, the model shows that the air masses arrived from East-Southeast direction, the same pattern appears at all elevations, showing that a deep air-layer was being affected. This indicated that the air masses may load with dust and pollutants originating outside Jeddah urban area. 


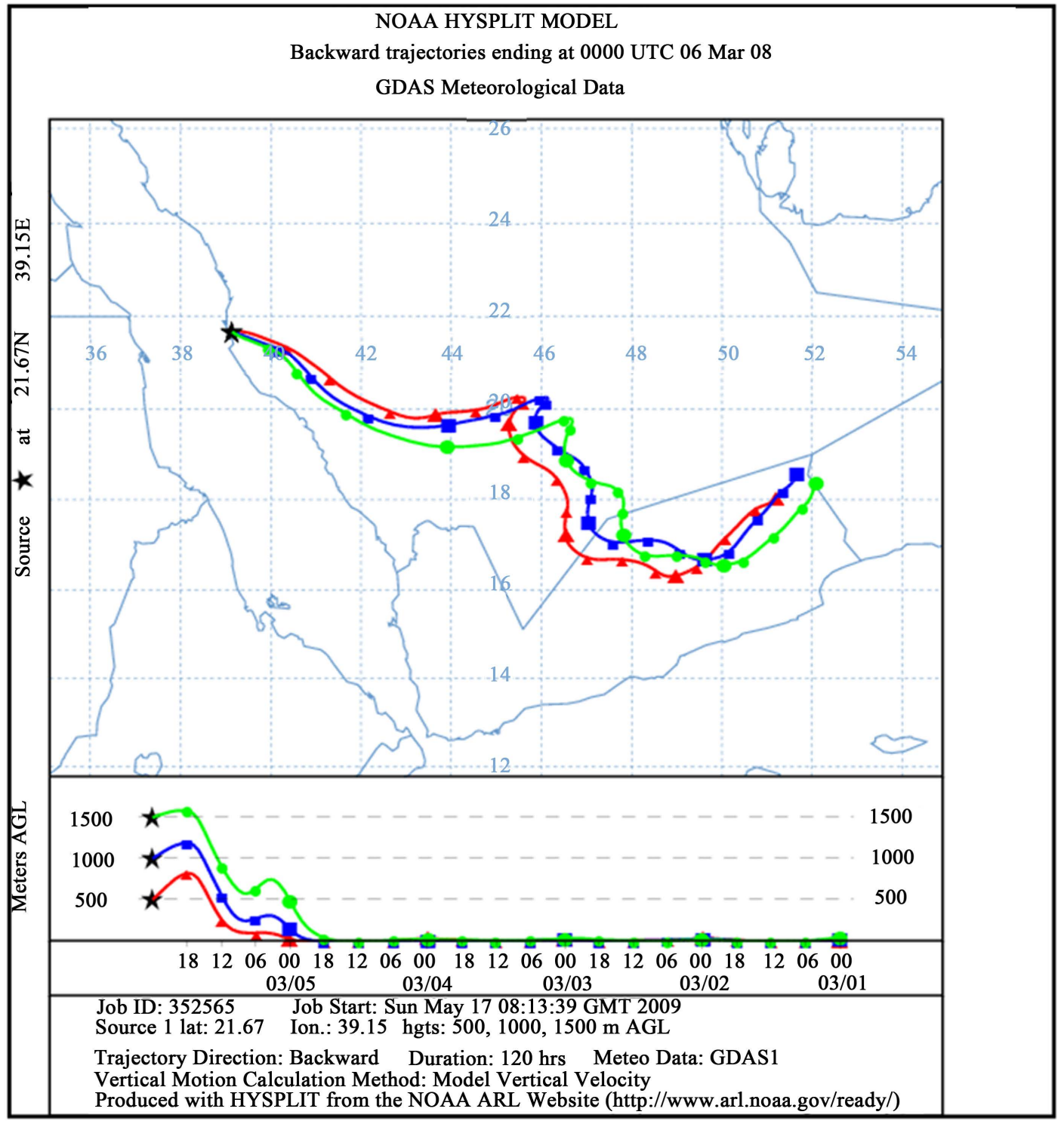

Figure 10. 5-day backward trajectory analysis started at altitudes of 500, 1000, and $1500 \mathrm{~m}$ at 00:00 UTC (0300 LT) on 06 March 2008 at Jeddah.

Table 2. Pearson correlation coefficients between daily $\mathrm{PM}_{10}$ and meteorological parameters in Jeddah during the period from March 2008-February 2009.

\begin{tabular}{ccccc}
\hline Site & Wind speed & Temperature & Relative humidity & Atmospheric Pressure \\
\hline stadium & -0.311 & -0.231 & 0.116 & 0.284 \\
Ruwais & -0.379 & -0.190 & 0.060 & 0.198 \\
\hline
\end{tabular}

\section{Conclusions}

This study had two aims, and the main conclusions regarding the first stated aim of investigating the long range transport contribute to high $\mathrm{PM}_{10}$ levels in two locations in Jeddah from March 2008 to February 2009: The USEPA 24-hr average concentration of $\mathrm{PM}_{10}\left(150 \mu \mathrm{g} / \mathrm{m}^{3}\right)$ was exceeded in 38 days at the two selected air quality monitoring sites in Jeddah. The exceedances were tabulated in 13 cases. The impact of remote sources on Jeddah urban air quality was assessed using HYSPLIT model through 5-day back trajectories. The results of this 


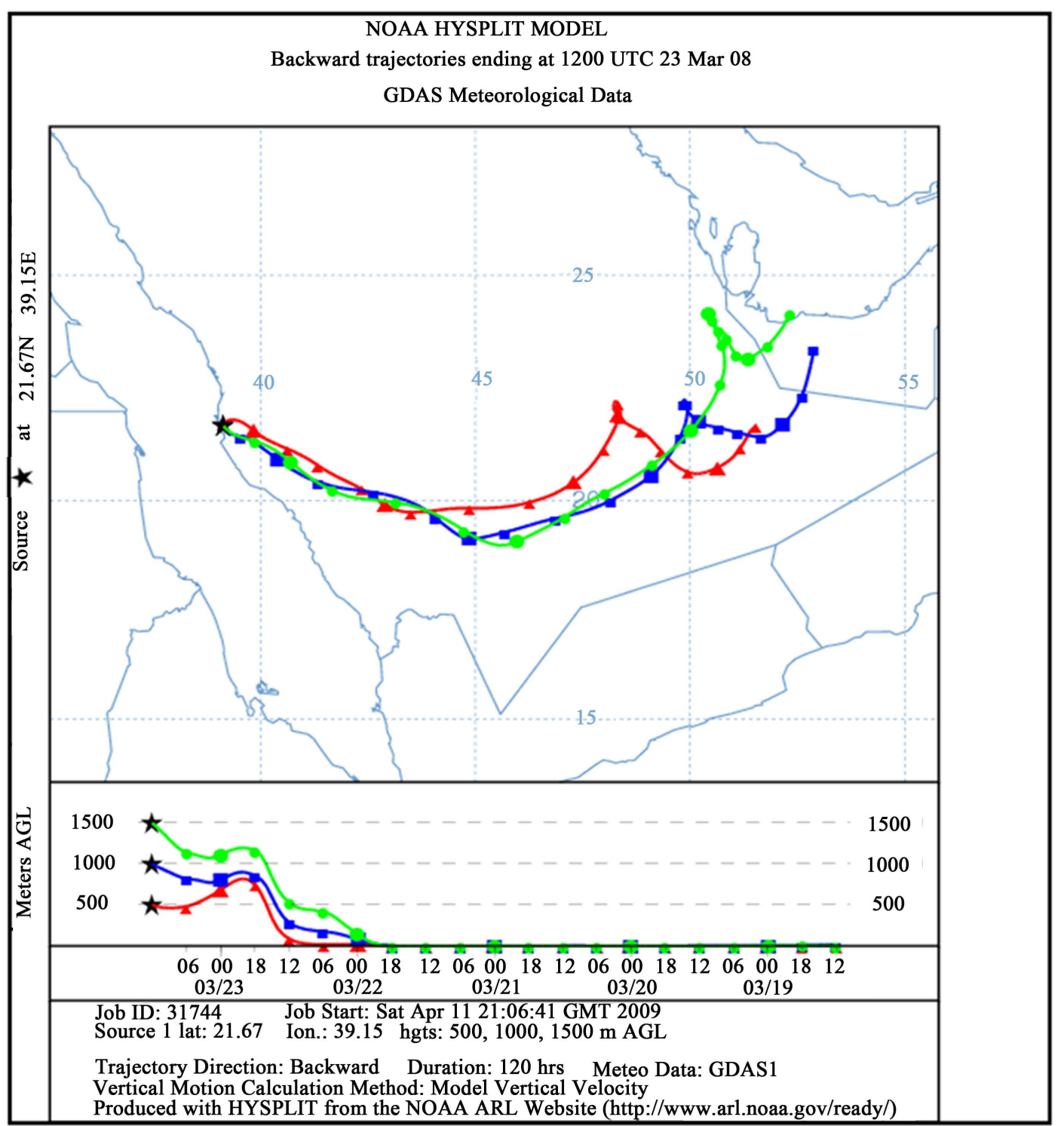

Figure 11. 5-day backward trajectory analysis started at altitudes of 500, 1000, and $1500 \mathrm{~m}$ at 12:00 UTC (15:00 LT) on 23 March 2008 at Jeddah.

analysis provided clear evidence of long-range transport of $\mathrm{PM}_{10}$ during all seasons. The most frequent air masses entering Jeddah and thereby influencing its air quality come from the East, specifically the SE and NE directions. This was particularly pronounced during March 2008, January and February 2009. The modeling and analysis of air mass trajectories demonstrate that Jeddah air quality was influenced strongly by Arabian Peninsula including Saudi Arabia mainland, the Arabian Gulf, 84\% of the air mass trajectories were originated in these regions, suggesting the impact of natural sources. $8 \%$ of the air mass trajectories were originated from Mediterranean Sea and southern Europe, mainly from W-NW sector. Another 8\% of the air mass trajectories were originated from North Africa and Sahara Desert, mainly from W-NW sector. The study demonstrated that the impact of anthropogenic sources from Europe to $\mathrm{PM}_{10}$ concentrations in Jeddah may be significant under certain meteorological conditions. Although this transport accounts for a small percentage of Jeddah $\mathrm{PM}_{10}$ levels on average, it can constitute about $8 \%$ of Jeddah's $\mathrm{PM}_{10}$ pollution during the study period. On the other hand, The main conclusions regarding the second aim of studying the relationship between $\mathrm{PM}_{10}$ level and other gaseous pollutants $\left(\mathrm{CO}, \mathrm{NO}_{\mathrm{x}}, \mathrm{SO}_{2}\right.$ and $\mathrm{O}_{3}$ ); and meteorological factors (relative humidity, temperature, atmospheric pressure, wind speed and wind direction): The diurnal variation of $\mathrm{PM}_{10}$ shows an early morning and late 
night peak $\left(\sim 84 \mathrm{\mu g} / \mathrm{m}^{3}\right)$ during 21:00-08:00 LT. $\mathrm{PM}_{10}$ concentrations during weekdays are perhaps somewhat higher compared to weekends. The daily $\mathrm{PM}_{10}$ concentrations correlated very strongly between the two monitoring sites. Clear linear relation $\left(\mathrm{R}^{2}=0.783\right)$ between $\mathrm{PM}_{10}$ measurements at stadium and $\mathrm{PM}_{10}$ levels at Ruwais location. Moderate positive correlation between $\mathrm{PM}_{10}$ and $\left(\mathrm{NO}_{\mathrm{x}}, \mathrm{NO}\right.$ and $\left.\mathrm{SO}_{2}\right)(\mathrm{R}=0.353, \mathrm{R}=0.347$ and $\mathrm{R}$ $=0.201$ ) respectively, and more consistent in Stadium site, demonstrating to some extent the common road traffic, mainly vehicular origin of primary $\mathrm{PM}_{10}$ and $\mathrm{NO}_{\mathrm{x}}$ and $\mathrm{NO}$ in urban areas. Moderate negative correlation between $\mathrm{PM}_{10}$ and $\left(\mathrm{O}_{3}\right.$, temperature and wind speed) $(\mathrm{R}=-0.276, \mathrm{R}=-0.231$ and $\mathrm{R}=-0.311)$ respectively, and more consistent in Stadium site. The negative correlation can be explained by the reaction of $\mathrm{O}_{3}$ with NO, which is a major sink for ozone, and the seasonal variation in case of temperature and wind speed. The correlation coefficients of the linear regression of $\mathrm{PM}_{10}$ against $\mathrm{NO}_{\mathrm{x}}$ and $\mathrm{NO}$ were generally weak $\left(\mathrm{R}^{2}=0.146\right.$ and $\mathrm{R}^{2}=$ 0.128) and suggest that non-proximate effect of different sources may contribute to the total $\mathrm{PM}_{10}$ concentrations at this site.

\section{References}

[1] Brunekreef, B. and Holgate, S.T. (2002) Air Pollution and Health. The Lancet, 360, 1233-1242. http://dx.doi.org/10.1016/S0140-6736(02)11274-8

[2] WHO (World Health Organization) (2005) Air Quality Guidelines Global Update 2005. Geneva.

[3] EEA (European Environment Agency) (2014) EEA Report No 5/2014: Air quality in Europe-2014 Report. Copenhagen.

[4] Samet, J. M., Dominici, F., Curriero, F.C., Coursac, I. and Zeger, S.L. (2000) Fine Particulate Air Pollution and Mortality in 20 US Cities, 1987-1994. The New England Journal of Medicine, 343, 1742-1749. http://dx.doi.org/10.1056/NEJM200012143432401

[5] Samoli, E., Peng, R., Ramsay, T., Pipikou, M., Touloumi, G., Dominici, F., Burnett, R., Cohen, A., Krewski, D., Samet, J. and Katsouyanni, K. (2008) Acute Effects of Ambient Particulate Matter on Mortality in Europe and North America: Results from the APHENA Study. Environmental Health Perspectives, 116, 1480-1486. http://dx.doi.org/10.1289/ehp.11345

[6] Pope C.A., Ezzati M. and Dockery, D.W. (2009) Fine-Particulate Air Pollution and Life Expectancy in the United States. The New England Journal of Medicine, 360, 376-386. http://dx.doi.org/10.1056/nejmsa0805646

[7] Pope, C.A. and Dockery, D.W. (2012) Health Effects of Fine Particulate Air Pollution: Lines that Connect. Journal of the Air \& Waste Management Association, 56, 709-742. http://dx.doi.org/10.1080/10473289.2006.10464485

[8] Ryall, D.B., Derwent, R.G., Manning, A.J., Redington, A.L., Corden, J., Millington, W., Simmonds, P.G., O’Doherty, S., Carslaw, N. and Fuller, GW. (2002) The Origin of High Particulate Concentrations over the United Kingdom, March 2000. Atmospheric Environment, 36, 1363-1378. http://dx.doi.org/10.1016/S1352-2310(01)00522-2

[9] Owega, S., Evans, G.J., Jervis, R.E., Fila, M., D’Souza, R. and Khan, B. (2004) Long-Range Sources of Toronto Particulate Matter $\left(\mathrm{PM}_{2.5}\right)$ Identified by Aerosol Laser Ablation Mass Spectrometry (LAMS). Atmospheric Environment, 38, 5545-5553. http://dx.doi.org/10.1016/j.atmosenv.2004.06.034

[10] Chen, Y., Sheen, P., Chen, E., Liu, Y., Wu, T. and Yang, C.C. (2004) Effects of Asian Dust Storm Events on Daily Mortality in Taipei, Taiwan. Environmental Research, 95, 151-155. http://dx.doi.org/10.1016/j.envres.2003.08.008

[11] Chan, Y.C., Vowles, P.D., McTainsh, G.H., Simpson, R.W., Cohen, D.D. and Bailey, G.M. (1999) Use of Modified Walkley-Back Method to Determine the Organic and Elemental Carbon Content of Urban Aerosols Collected on Glass Fiber Filters. Chemosphere, 31, 4403-4411. http://dx.doi.org/10.1016/0045-6535(95)00308-U

[12] Rodriguez, S., Querol, X., Alastuey, A., Viana, M., Alarcon, M., Mantilla, E. and Ruiz, C.R. (2004) Comparative PM10-PM2.5 Source Contribution Study at Rural, Urban and Industrial Sites during PM Episodes in Eastern Spain. Science of the Total Environment, 328, 95-113. http://dx.doi.org/10.1016/S0048-9697(03)00411-X

[13] Kim, E., Larson, T.V., Hopke, P.K., Slaughter, C., Sheppard, L.E. and Claiborn, C. (2003) Source Identification of PM2.5 in an Arid Northwest U.S. City by Positive Matrix Factorization. Atmospheric Research, 66, 291-305. http://dx.doi.org/10.1016/S0169-8095(03)00025-5

[14] Querol, X., Alastuey, A., Ruiz, C.R., Artiñano, B., Hanssonc, H.C., Harrison, R.M., Buringh, E., ten Brink, H.M., Lutz, M., Bruckmannh, P., Straehl, P. and Schneider, J. (2004) Speciation and Origin of PM10 and PM2.5 in Selected European Cities. Atmospheric Environment, 38, 6547-6555. http://dx.doi.org/10.1016/j.atmosenv.2004.08.037

[15] Hellack, B., Quass, U., Beuck, H., Wick, G., Kuttler, W., Schins, R.P.F. and Kuhlbusch, T.A.J. (2015) Elemental Composition and Radical Formation Potency of $\mathrm{PM}_{10}$ at an Urban Background Station in Germany in Relation to Origin of Air Masses. Atmospheric Environment, 105, 1-6. http://dx.doi.org/10.1016/j.atmosenv.2015.01.033 
[16] Sillanpää, M., Hillamo, R., Saarikoski, S., Frey, A., Pennanen, A. and Makkonen, U. (2006) Chemical Composition and Mass Closure of Particulate Matter at Six Urban Sites in Europe. Atmospheric Environment, 40, 212-223. http://dx.doi.org/10.1016/j.atmosenv.2006.01.063

[17] Mazzei, F., D’Alessandro, A., Lucarelli, F., Nava, S., et al. (2008) Characterization of Particulate Matter Sources in an Urban Environment. Science of the Total Environment, 401, 81-89. http://dx.doi.org/10.1016/j.scitotenv.2008.03.008

[18] Amato, F., Pandolfi, M., Viana, M., Querol, X., Alastuey, A. and Moreno, T. (2009) Spatial and Chemical Patterns of $\mathrm{PM}_{10}$ in Road Dust Deposited in Urban Environment. Atmospheric Environment, 43, 1650-1659. http://dx.doi.org/10.1016/j.atmosenv.2008.12.009

[19] Draxler, R.R., Gillette, D.A., Kirkpatrick, J.S. and Heller, J. (2001) Estimating PM10 Air Concentrations from Dust Storms in Iraq, Kuwait and Saudi Arabia. Atmospheric Environment, 35, 4315-4330. http://dx.doi.org/10.1016/S1352-2310(01)00159-5

[20] Walters, K., Traxler, K., Gilford, M., Arnold, R., Bonam, R. and Gibson, K. (1992) Gulf War Weather. USAF ETAC/ TN-92/003, USAF Environmental Technical Applications Center, Scott Air Force Base, IL, 245, 5438-6222.

[21] Safar, M.I. (1985) Dust and Duststorms in Kuwait. Directorate General of Civil Aviation, Meteorological Department, Kuwait, 212.

[22] PME (Presidency of Meteorology and Environment) (2005) PME-AMMNET 2003 Annual Report. PME Publication, Saudi Arabia.

[23] Draxler, R.R. and Hess, G.D. (1997) Description of the Hysplit_4 Modeling System. NOAA Tech Memo ERL ARL-224, Dec, 24 p.

[24] Draxler, R.R. and Hess, G.D. (1998) An Overview of the HYSPLIT_4 Modeling System of Trajectories, Dispersion, and Deposition. Australian Meteorological Magazine, 47, 295-308.

[25] Pillai, P.S. and Moorthy, K.K. (2001) Aerosol Mass Size Distribution at a Tropical Coastal Environment: Response to Mesoscale and Synoptic Processes. Atmospheric Environment, 35, 4099-4112. http://dx.doi.org/10.1016/S1352-2310(01)00211-4 